\title{
Prevalence of Escherichia coli in chicken carcasses from Mansoura, Egypt
}

\author{
Abo El-magd, E. E., ${ }^{1}$ Sallam, k. I., ${ }^{2}$ Abd el-ghany, S. M. ${ }^{2}$ and Ramadan, H. H. ${ }^{3}$ \\ ${ }^{1}$ Oncology Center Mansoura University, Egypt \\ ${ }^{2}$ Department of Food Hygiene and Control, Faculty of Veterinary Medicine, Mansoura University, Egypt. \\ ${ }^{3}$ Department of Hygiene and Zoonoses, Faculty of Veterinary Medicine, Mansoura University, Egypt.
}

\section{ABSTRACT}

\begin{abstract}
Objective: This study ended to detect the prevalence and public health important of Escherichia coli in chicken carcasses in Mansoura City.

Procedures: A total of 100 whole frozen chicken carcasses purchased from supermarkets distributed at Mansoura city were examined to detect Escherichia coli.

Results: Out of the 100 examined carcasses, 98 chicken carcasses were contaminated with Escherichia coli with an incidence rate $98 \%$.

Conclusion and clinical relevance: This study revealed that chicken meat are highly contaminated with $E$. coli and play an important role in transmission of $E$. coli to human, therefore special precautions and hygienic measures must be applied in abattoir during evisceration and dressing of carcasses, and in-home during handling and cooking of chickens to protect consumers from $E$. coli foodborne infection.
\end{abstract}

Keywords: Chicken; carcasses; E. coli; PCR

\section{INTRODUCTION}

Poultry is one of the most important sources of good quality protein for human being. They are economically cheaper than red meat, low in calories, source of both saturated and unsaturated fatty acids and its protein is good source of essential amino acids, easily digested and has palatable taste. Poultry and poultry products are among the main food sources most often incriminated in outbreaks of human food-borne infection especially that caused by Escherichia coli (Panisello et al. 2000).

Escherichia coli is one of the most causes of food-borne pathogens, with a big effect on public health concern, poultry meat was incriminated in the transmition of Escherichia coli worldwide and infection mainly occurs due to crosscontamination from equipment, utensils and via food handlers handling raw carcasses or undercooked poultry meat products (Adeyanju and Ishola 2014). Escherichia coli is naturally inhabited in the intestinal tracts of warm-blooded animals and humans, and used as an indicator for fecal contamination, and possibility of contamination by enteric pathogens especially Shiga Toxin-producing Escherichia coli (STEC) (Miranda et al., 2008).

Escherichia coli become one of the most microbial agents that are implicated in human extraintestinal infections including urinary tract infections (UTIs), sepsis, and neonatal meningitis which difficult to be treated due to its resistance to the commonly used antibiotics (Johnson et al. 2012 and Manges and Johnson 2012). Due to the potential public health problem of these bacteria, this study is planned to throw the light on prevalence, and incidence of $E$. coli isolates from chicken carcasses distributed in Mansoura city, Egypt.

\section{MATERIALS AND METHODS}

\subsection{COLLECTION OF SAMPLES}

Between December 2016 and May 2017, a total of 100 whole frozen chicken carcasses were purchased from supermarkets distributed at Mansoura city, Egypt. Wherein they are sold retail, in a deep-frozen state. every sample was separately packaged into a polyethylene bag and transferred in icebox to the laboratory for bacteriological examinations, in Department of Food Hygiene and Control, Faculty of Veterinary Medicine, Mansoura University.

\subsection{ISOLATION AND IDENTIFICATION OF ESCHERICHIA COLI:}

\subsubsection{Enrichment:}

Whole poultry carcass was separately shacked with sterile tryptone soya broth, $225 \mathrm{ml}$ for each carcass (Oxoid CM0989). Then incubated the resultant suspension at $37^{\circ} \mathrm{C}$ for $18-24$ hours.

\subsubsection{Selective plating:}

Enriched cultures were streaked onto sterile MacConkey agar (Oxoid CM1169) supplemented with cefixime (final concentration $0.05 \mathrm{mg} / \mathrm{L}$ ), then the plates were incubated at $37^{\circ} \mathrm{C}$ for 24 hours. Every plate was examined for typical E. coli colonies. 


\subsection{BIOCHEMICAL IDENTIFICATION OF PRESUMPTIVE E. COLI:}

A total of 600 colonies exhibiting pink color and able to ferment lactose were culture on nutrient agar (Oxoid CM0003) and then subjected to different biochemical tests purposed for conventional identification of $\mathrm{E}$. coli, (Indole test, Methyl red test, Voges-Proskauer test, and citrate utilization test and Urease test) isolates confirmed biochemically as $\mathrm{E}$. coli if give theses result with (Indole +, Methyl +, Voges -, citrate -, Urease -)

\subsection{MOLECULAR IDENTIFICATION OF E. COLI:}

One hundred biochemically identified E. coli isolates from chicken samples (each chicken represented by a single isolate) were subjected to molecular identification

\subsubsection{DNA extraction:}

Firstly, every isolate was cultured in nutrient broth (Oxoid $\mathrm{CM0001)}$ and incubated overnight at $37^{\circ} \mathrm{C}, 5 \mathrm{ml}$ from each bacterial culture was centrifugation at $3000 \mathrm{rpm}$ for 15 minutes for isolation of chromosomal DNA, discarded the suspensions then suspended the collected cells in $1.5 \mathrm{ml} \mathrm{TE}$ (Trise-EDTA) buffer, then transferred into 2-ml centrifuge tube and centrifuged for 1 minute at $8000 \mathrm{rpm}$ for collecting the washed cell pellet. then discarded the supernatant and the bacterial pellet was resuspended with $500 \mu \mathrm{l}$ of TE and incubated at $37^{\circ} \mathrm{C}$ for 2 hours after the addition of lysozyme $(10 \mathrm{mg} / \mathrm{ml})$ and RNase $A(50 \mu \mathrm{g} / \mathrm{ml})$. Then isolated the chromosomal DNA with using of a Maxwell 16 cell DNA purification kit (Promega Corporation, Madison, WI, USA) according the protocol of genomic DNA purification, which supplied by the manufacturer. A volume of the resultant chromosomal DNA was then taken to be diluted 20 times in TE for using as template for PCR amplification of the target gene.

\subsubsection{E. coli confirmation}

Isolates with typical Escherichia coli biochemical results (+ + - - -) were examined by the use of the specific PCR to determine the presence of uidA gene specific for $E$. coli. We constructed one primer set for the amplification of uidA gene have the following equence 5'- ATGCCAGTCCAGCGTTTTTGC-3' and 5'- AAAGTGTGGGTCAATAATCAGGAAGTG -3' which can amplify an amplicon of $1487 \mathrm{bp}$, PCR amplification was conducted in a $20-\mu$ l reaction mixture using GoTaq Green Master Mix, ready to use solution containing Taq DNA polymerase (Promega Corporation) supplied in 2X Green GoTaq reaction buffer $(\mathrm{pH}$ 8.5). PCR reaction mixture consisted of $1 \mu \mathrm{l}(10 \mathrm{pmol})$ from each of antisense and sense primers, $2 \mu$ l DNA template, $10 \mu$ l GoTaq Master Mix 2X (1 U Taq DNA polymerase, $400 \mu \mathrm{M}$ dATP, $400 \mu \mathrm{M}$ dCTP, $400 \mu \mathrm{M}$ dGTP, $400 \mu \mathrm{M}$ dTTP and $3 \mathrm{mM} \mathrm{MgCl}_{2}$ ) and autoclaved water 6 $\mu$ l. The mixture was subjected to amplification by 35 cycles of in Gene Amp PCR system 2700 (Applied Biosystems, Foster City, CA, USA). The first cycle was preceded by denaturation 4 minutes at $95{ }^{\circ} \mathrm{C}$ for. Each cycle performed for aerolysin (uidA) gene consisted of denaturation at $95{ }^{\circ} \mathrm{C}$ for 40 seconds, annealing at $63{ }^{\circ} \mathrm{C}$ for 30 seconds, and extension for 1.5 minutes at $72{ }^{\circ} \mathrm{C}$ followed by a final extension for 4 minutes at $72{ }^{\circ} \mathrm{C}$ followed the last cycle.

\subsubsection{Electrophoresis of PCR products}

Separated the PCR-amplified products of each reaction mixture by subjecting $4 \mu \mathrm{l}$ aliquots to agarose (1.5\%) gel electrophoresis for 30 minutes at $100 \mathrm{~V}$ followed by a 25minute staining in $1 \%$ solution of ethidium bromide solution. Finally, visualization and photographing the separated PCR products under UV illumination. With using E. coli (ATCC 25922) as a positive control in the present study.

\section{RESULTS}

From the 600 isolates which collected from 100 chicken carcasses only 434 isolates were identified as E. coli by biochemical tests representing a prevalence of $(72.3 \%$; $434 / 600)$ with incidence of $(100 \%)$ represented at figure (1). From 434 biochemically identified $\mathrm{E}$. coli isolates, one hundred E. coli isolates from chicken samples (each chicken represented by a single isolate) subjected to molecular identification, and found that 98 isolates confirmed as E. coli by molecular method with incidence $98 \%$ in chicken represented at figure (2).

Figure (1): Escherichia coli presumptive isolates confirmed based on conventional identification

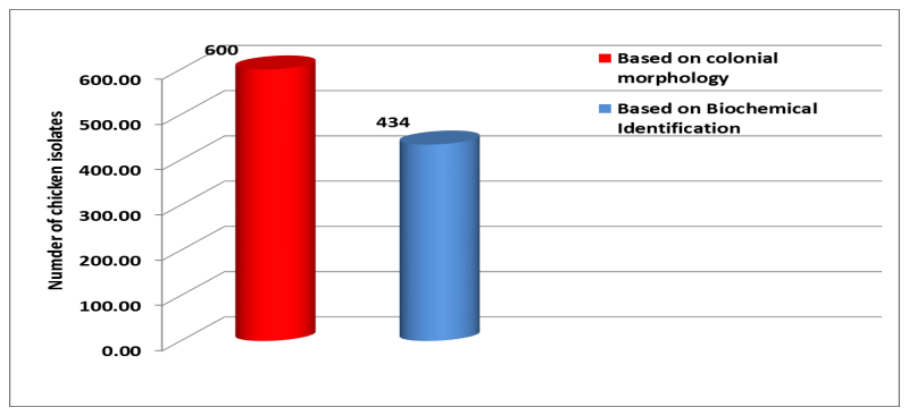

Figure 2: Escherichia coli presumptive isolates confirmed based on and molecular identification

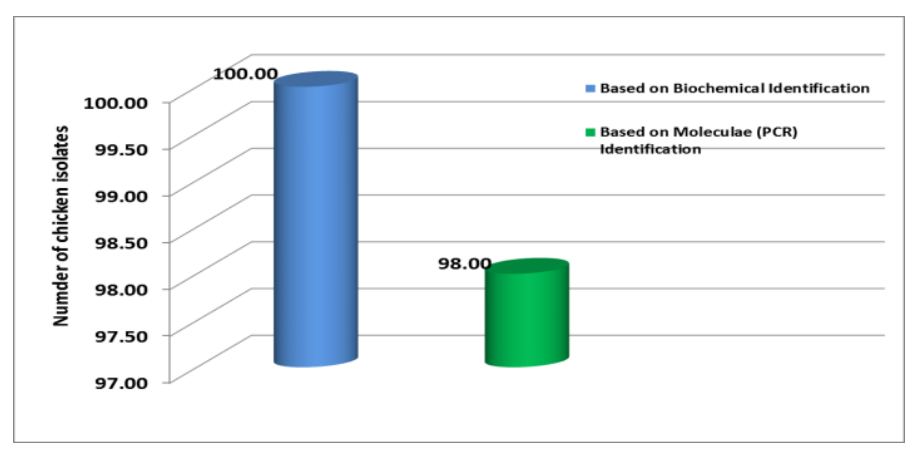

Figure (A),(B) 

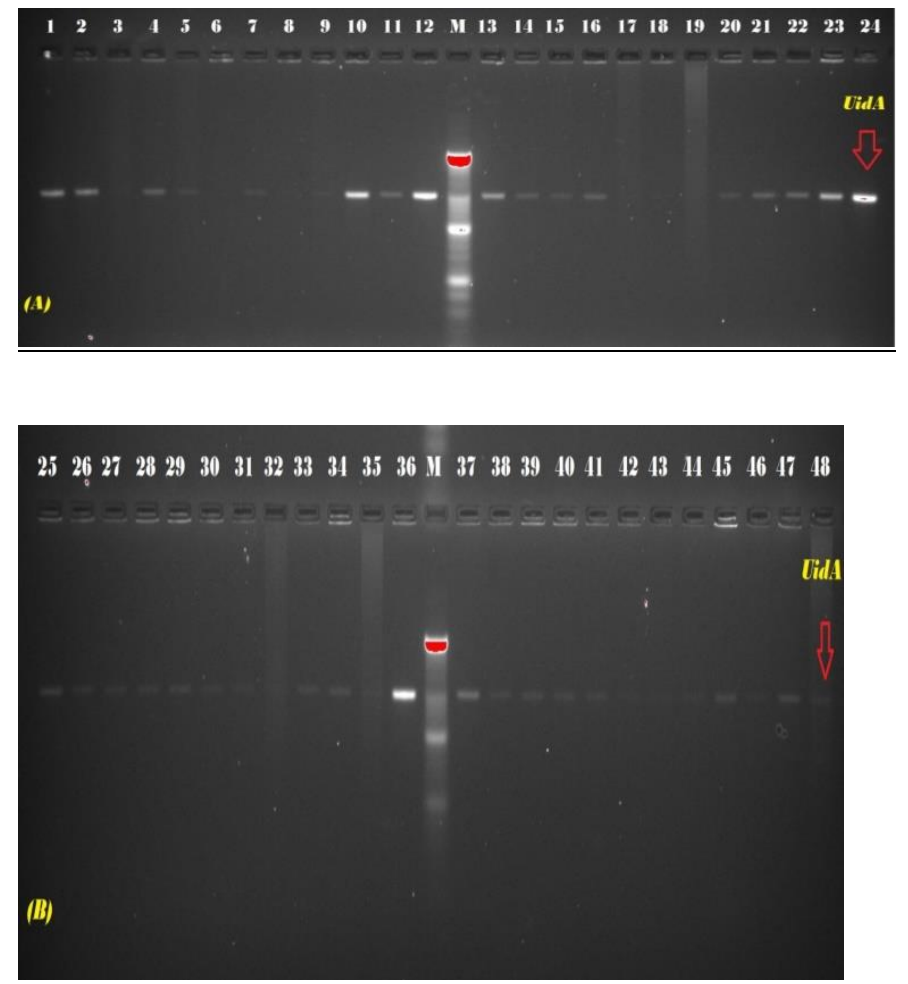

Figure (A), (B) Agarose gel electrophoresis for PCR analysis of (uidA) gene in $E$. coli isolated from chicken carcasses. Chromosomal DNA from $(n=100)$ Conventional identified $E$. coli used as a template for PCR amplification using specific oligonucleotide primer for uidA gene.

\section{DISCUSSION}

E. coli has been incriminatory in a variety of diseases in poultry for example colisepticaemia, peritonitis, coligranuloma, pericarditis, air sacculitis, omphalitis and oophoritis, causing about 5-50 \% mortality in poultry flocks (Roy et al., 2006). Also, poultry and poultry products are among the main food sources most often incriminated in outbreaks of human food-borne infection especially colibacillosis (Panisello et al., 2000). And due to the potential public health problem of these bacteria, this study is planned to throw the light not only on the prevalence, but also incidence of $E$. coli isolates from chicken carcasses distributed in Mansoura city, Egypt. With using conventional and molecular methods which revealed that chicken carcasses highly contaminated with $E$. coli with incidence $98 \%$.

Also, high incidence of E. coli $93.7 \%$ was reported by (Abd El-Tawab et al. 2016) when examined 1284 chicken samples from Giza and Qalubia governorates, Egypt, found that 1204 samples positive for $E$. coli. There are several studies in different countries which showed high incidence of $E$. coli, like result of study in Yugoslavia by (Prukner E. 1986) reported high incidence $81.46 \%$, also high incidence of $88.2 \%$ was mentioned by El-sukhon et al. (2002) in Jordan. In Egypt Abd El-Aziz et al. (2007) isolated E. coli in a percentage of $90 \%$. Barros et al. (2013) could detect $E$. coli in chicken meat by a percentage of $82.5 \%$. Liu et al. (2018) found that E. coli incidence was nearly $80 \%$ of the 2,452 meat samples ( $93 \%$ of meat source poultry products).

Intermediate percentages of incidences of $E$. coli were reported by Adeyanju and Ishola (2014) could isolate E. coli from chicken meat collected retail markets with an incidence of $43.4 \%$ (43/99), (Barbour et al. 1985) isolated E. coli with incidence of $45.4 \%$. Abd El Tawab et al. (2015) found that $E$. coli with incidence of $44 \%, 75 \%$ among imported chicks and from local broiler chickens, respectively. Another intermediate result was reported by Saha et al. (2003) who isolated E. coli with incidence of $58.18 \%$, Hashem et al. (2012) who isolated $E$. coli in a percentage of $54.55 \%$ and by Kegode et al. (2008) who recovered $E$. coli for chicken with an incidence of $68 \%$ in Fargo metropolitan area, USA.

Lower incidence value was reported by Abd El Tawab et al. (2015a) who detected E. coli in $15.7 \%$ and $15.8 \%$ of examined apparently healthy broiler chickens collected in winter seasons from December to February and summer seasons (from June to August), respectively from Menofya government, Egypt. Also, reported by Adesiji et al. (2011) who found that $E$. coli incidence was $26 \%$ from chicken, beef, goat and pork samples, with $16 \%$ in chicken only and by Ukut et al. (2010) who could isolate $E$. coli from poultry by incidence rate of $11.1 \%$.

The differences in rates of isolation may be attributed to many reasons such as immune status of the bird, vaccination programs which used, use of medication and hygienic status of the poultry abattoir.

The outcome of this study provides that chicken carcasses highly contaminated with $E$. coli isolates, and it is very important to increase the hygienic control to decrease contamination of the chicken carcasses with $E$. coli and to decrease possibility of transmission of $E$. coli to human.

\section{Conflict of interest}

Authors declare that they have no conflict of interest

\section{REFERENCES}

Abd El Tawab, A. A., Ammar, A. M., Nasef, S. A. and Reem M. Reda, R. M. (2015): Prevalence of E.Coli in diseased chickens with its antibiogram pattern. Benha Vererinary Medical Journal, 28(2):224-230.

Abd El-Aziz, E.E., Hassan, A.M. and Badr, J.M. (2007): In vitro efficacy of some antimicrobials on the E. coli and Mycoplasmal isolates from cases of chronic respiratory disease in broilers in Egypt. Zag. Vet. J., 35(3): 40-49.

Abd El Tawab, A. A., Abd El Aal, S. A., mazied, E. M., and EL. Morsy, D. A. (2015a): Prevalence of E. coli in broiler chickens in winter and summer seasons by application of PCR with its antibiogram pattern. Benha Veterinary Medical Journal, 29(2):119-128.

Abd El-Tawab, A. A., Hassan, W. M., El-Seedy, F. R. and Abdel-Satar, H. (2016): Phenotypic and genotypic characterization of multi drug resistant $E$. coli isolated from chickens. Benha Journal of Applied Sciences (BJAS), 1(2): 1-6

Adesiji, Y. O., Alli, O. T., Adekanle, M. A. and Jolayemi, J. B. (2011): Prevalence of Arcobacter, Escherichia coli, Staphylococcus aureus and Salmonella 
species in retail raw chicken, pork, beef and goat meat in Osogbo, Nigeria. Sierra Leone. J Biomed Res 3(1):8-12.

Adeyanju and Ishola (2014): Salmonella and Escherichia coli contamination of poultry meat from a processing plant and retail markets in Ibadan, Oyo State, Nigeria Springer Plus,3:139 Page 2-9

Barbour, E. K., Nabbed, N. H. and Al-Nakhli, H. M. (1985): Use of epidemiologic markers to identify the source of E. coli infections In Poultry. Am. J. Vet. Res., 46(4):989-91.

Barros, L. S. S., Silva, R. M., Silva, I. M., Baliza, M .D. and Virgı́lio, F. F. (2013): Escherichia coli from cellulitis lesions in broilers. Food Measure, 7:40-45

Choo E., Jang S. S., Kim K., Lee K. G., Heu S. and Ryu S. (2007): Prevalence and genetic diversity of Bacillus cereus in dried red pepper in Korea. J. Food Prot., 70: 917-922.

El-Sukhon, S. N., Musa, A. and Al-Attar, M. (2002): Studies on the Bacterial Etiology of Airsacculitis of Broilers in Northern and Middle Jordan with Special Reference to Escherichia coli, Ornithobacterium rhinotracheale, and Bordetellaavium. Avian Dis., 46(3): 605-612

Gomis, S. M., Riddell, C., Potter, A. A., and Allan, B. J. (2001): Phenotypic and genotypic characterization of virulence factors of Escherichia coli isolated from broiler chickens with simultaneous occurrence of cellulitis and other colibacillosis lesions. The Canadian J. Vet. Res., 65: 1-6.

Hashem, M., Elahi, M., Mannan, M., Kabir, M., Kashem, M. and Pallab, M. (2012): Isolation, identification and antibiogram of Escherichia coli from broiler at Chittagong District in Bangladesh. Wayamba J. of Ani. Sci. 312316.

Johnson, T. J., Logue, C. M., Johnson, J. R., Kuskowski, M. A., Sherwood, J. S., Barnes, H. J., DebRoy, C., Wannemuehler, Y. M., Obata-Yasuoka, M., Spanjaard, L., Nolan, L. K. (2012): Associations between multidrug resistance, plasmid content, and virulence potential among extraintestinal pathogenic and commensal Escherichia coli from humans and poultry. Foodborne Pathog Dis., 9:37-46.

Kegode, R. B., Doetkott, D. K., Khaitsa, M. L. and Wesley, M. L. (2008): Occurrence of Campylobacter species, Salmonella species and generic Escherichia coli in meat products from retail outlets in the Fargo metropolitan area, Journal of Food Safety 28:111-125.

Liu, C. M., Stegger, M., Aziz, M., Johnson, T. J., Waits, K., Nordstrom, L., Gauld, L., Weaver, B., Rolland, D., Statham, S., Horwinski, J., Sariya, S., Davis, G. S., Sokurenko, E., Keim, P., Johnson, J. R. and Price, L. B. (2018):
Escherichia coli ST131-H22 as a foodborne uropathogen. mBio 9: e0047018, DOI: $10.1128 / \mathrm{mBio} .00470-18$.

Manges, A. R., and Johnson, J. R. (2012): Food-borne origins of Escherichia coli causing extraintestinal infections. Clin. Infect. Dis. 55:712-719.

Miranda, J., Vazquez, B., Fente, C. and Barros-Velázquez J. (2008): Antimicrobial resistance in Escherichia coli strains isolated from organic and conventional pork meat: A comparative survey. European Food Research and Technology 226(3):371-375.

Paniselloa, J., Rooney, R., Quantick, P. and well-Smith, R. (2000): Application of foodborne disease outbreak data in the development and maintenance of HACCP systems. International Journal of food microbiology, 95(3): 221234.

Prukner, E. (1986): Frequency and epidemiol-ogical significance of virulent E. coli strains indead poultry in Yugoslavia and sensitivity toantimicrobial agents.Vet.Archival.vol.56 (5), PP.227-23, 1986.

Rasmussen, M. M., Opintan, J. A., Frimodt-Møller, N. and Styrishave B. (2015): Beta-lactamase producing Escherichia coli isolates in imported and locally produced chicken meat from Ghana. PLoS ONE 10: e0139706.

Roshdy, H., Abd El-Aziz, S. and Refai, M. (2012): Incidence of E. coli in chickens and ducks in different governorates in Egypt. 1st Conf. of An. Health Res. Inst. Assoc., 420-426.

Roy, P., Purushothaman, V., Koteeswaran, A. and A.S.Dhillon A. (2006): Isolation, Characterization, and Antimicrobial Drug Resistance Pattern of Escherichia coli Isolated from Japanese Quail and their Environment. J. Appl. Poult. Res., 15:442-446.

Saha, A., Hul, A. K., Das, R., Roy, J. P., Ray, N. and Mahata T. K. (2003): Occurrence of Escherichia coli from broiler birds in Bengl and their antibiogram. Indian J.Ani. H., 42 (2)

Ukut, I. O., Okonko, I.O., Ikpoh, I.S., Nkang, A. O., Udeze, A. O., Babalola, T. A., Mejeha, O. K. and Fajobi, E. A. (2010): Assessment of bacteriological quality of fresh meats sold in Calabar metropolis, Nigeria. Electron J. Environ Agr Food Chem., 9(1):89-100, ISSN: 1579-4377. 